\title{
Sağlık Alanındaki Ön Lisans Öğrencilerinde Akılı Telefon Bağımlıı̆ğı Üzerine Nitel ve Nicel Bir Çalışma
}

\section{A Qualitative and Quantitative Study on Smartphone Addiction in the Students' of Associate Students' in the Field of Health}

\author{
${ }^{1}$ Canan BIRIMOĞLU OKUYAN, ${ }^{2}$ Süreyya NUR, ${ }^{3}$ Fatma KARASU, ${ }^{4}$ Ebru DEVECI \\ ${ }^{1}$ Sakarya Uygulamalı Bilimler Üniversitesi, Sağlık Bilimleri Fakültes \\ ${ }^{2}$ Hatay Mustafa Kemal Üniversitesi, Sağlık Hizmetleri Meslek Yüksekokulu \\ ${ }^{3}$ Kilis 7 Aralık Üniversitesi, Y.S. Sağlık Bilimleri Fakültesi \\ ${ }^{4}$ Hasan Kalyoncu Üniversitesi, Sağlık Hizmetleri Meslek Yüksekokulu
}

Canan Birimoğlu Okuyan: https://orcid.org/0000-0002-7339-6072

Süreyya Nur: https://orcid.org/0000-0002-8504-5309

Fatma Karasu: https://orcid.org/0000-0002-7347-0981

Ebru Deveci: https://orcid.org/0000-0003-0166-4741

\section{ÖZ}

Amaç: Bu araştır ma, sağlık alanındaki ön lisans bölümünde öğrenim gören öğrencilerde akıllı telefon bağıml1lığının (nomofobi) çeşitli faktörler üzerine etkisini belirlemek amacıyla yapılmıştır.

Materyal ve Metot: Araştırma nicel ve nitel tipte yap1lan çalışmadır. Çalışmanın evrenini, bir devlet üniversitesinin ön lisans bölümünde öğrenim gören öğrenciler oluşturmuş ve örneklem seçimine gidilmeyerek çalışmaya katılmayı kabul eden 439 öğrenciye ulaşılmıştır. Araştırmanın nitel kısmı için, nicel boyuta katılan ve çalışmanın nitel k1smına katılmaya gönüllü olan öğrencilerden 13'i rastsal olarak seçilmiş ve görüşmeler yapılmıştır. Veriler Mayıs-Ekim 2019 tarihleri arasında toplanmıștır.

Bulgular: Öğrenciler in yanında şarj taşıma, cep telefonunu günlük kontrol etme sıklığı, günlük cep telefonu kullanma süresi, son zamanlarda telefonun aile bağlarında kopukluğa sebep olup olmadığı durumları ile Nomofobi ölçeği puan ortalamaları arasında istatistiksel olarak önemli bir ilişki bulunmuştur $(\mathrm{p}<0,05)$. Öğrencilerin $\%$ 57,5'inde orta düzeyde nomofobi olduğu saptanmıştır.

Sonuç: Öğrencilerin nomofobi düzeylerinin ortalamanın üzerinde olduğu; cep telefonunun özellikle göz kuruluğuna, omuz ve baş ağrısına, kullanılan el ve parmakta ağrı, uyuşukluk hissi oluşturduğu belirlenmiştir.

Anahtar Kelimeler: Akıllı telefon, nomofobi, üniversite ögrencileri

\begin{abstract}
Objective: The aim of this study was to determine the effect of Smart phone Addiction (nomophobia) on various factors in associate degree students in the field of health. Materials and Methods: This is a qualitative and quantitative study. The universe of the study consisted of students studying at associate degree departments of a state university and 439 students who accepted to participate in the study were not reached by selecting the sample. For the qualitative part of the study, 13 of the students who participated in the quantitative dimension and volunteered to participate in the qualitative part of the study were randomly selected and interviews were conducted. Data were collected between May-October 2019.

Results: Carrying charge with students, frequency of checking mobile phone daily, daily mobile phone usage time, whether or not the phone caused a break in family bonds. There was a statistically significant relationship between the mean score of Nomophobia scale $(p<0.05)$. $57.5 \%$ of the students had moderate nomophobia.

Conclusions: The nomophobia levels of the students were above the middle; It was determined that the mobile phone caused pain, numbness and pain in the hand and finger, especially in the dry eye, shoulder and headache. Keywords: Cell phone, the nomophobia, university students
\end{abstract}

\author{
Sorumlu Yazar / Corresponding Author: \\ Canan Birimoğlu Okuyan \\ Dr.Öğr.Üyesi; Sakarya Uygulamalı Bilimler Üniversitesi, Sağlık \\ Bilimleri Fakültesi, \\ Tel: +90 05539272035 \\ E-mail: cananbirimoglu@gmail.com
}

Yayın Bilgisi / Article Info:

Gönderi Tarihi/ Received: 11/03/2020

Kabul Tarihi/ Accepted: 06/06/2020

Online Yayın Tarihi/ Published: 30/09/2020

Atıf / Cited: Birimoğlu Okuyan C et al. Sağlık alanındaki ön lisans öğrencilerinde akıllı telefon bağımlılığı üzerine nitel ve nicel bir çalışma. Online Türk Sağllk Bilimleri Dergisi 2020;5(3):455-463. doi: 10.26453/otjhs.702051 


\section{GIRIȘ}

Teknolojinin gelişmesiyle birlikte akıllı telefonların sunduğu olanaklar ve dolayısıyla kullanımı her geçen gün artmakta ${ }^{1,2}$ ve insanların, iletişim kurma ve mesajlaşma, e-postalarını yönetme, oyun oynama, sosyal ağları kullanma, alı̧veriş yapma gibi birçok işlevlerini cep telefonu aracıllı̆ıyla yaptıkları için ${ }^{3}$ günlük yaşamları daha kolay hale gelmektedir. ${ }^{1,2}$ Kullanımı artan cep telefonlarının $(\% 96,9)$ kullanım amacı ise en çok sosyal medyadır. ${ }^{4}$

Bireyin temel ihtiyaçlarını karşılamada yardımeı olan akıllı telefonlar, kullanıma bağlı olarak beraberinde akıllı telefon bağımlılı̆̆ı gibi çeşitli problemler de getirebilmektedir. ${ }^{5} \mathrm{Bu}$ problemlerden en önemlisi her geçen gün yaygınlaşan akıllı telefon bağımlılığıdır (nomofobi). Kişinin cep telefonundan uzak kaldığında yaşadığı korku ve kaygı olarak adlandırılan nomofobi, ${ }^{6}$ üniversite öğrencileri için risk faktörü olarak kabul edilmektedir., ${ }^{7,8}$ Nomofobinin sosyal fobiyle, ${ }^{6}$ cinsiyetle, günlük mesaj gönderme sayısı ve telefonla günlük konuşma süresiyle, ${ }^{9}$ yalnızlık, mutluluk ve benlik saygisıyla ${ }^{10}$ anlamlı ilişkisi olduğunu tespit eden araştırmalar bulunmaktadır. Ancak, sağlık üzerine etkisini inceleyen çalışmaya rastlanılmamıştır. Bu sonuçtan hareketle araştırma, sağlık alanındaki ön lisans bölümünde okuyan öğrencilerde akıllı telefon bağımlılığının çeşitli faktörler açısından etkisini belirlemek amacıyla yapılmıştır.

\section{MATERYAL VE METOT}

Araştırma, bir devlet üniversitesinin ön lisans tıbbi hizmetler ve teknikler bölümünde öğrenim gören öğrencilerde akıllı telefon bağımlılı̆̆ının çeşitli faktörler üzerine etkisini belirlemek amacıyla yapılmıştır.

Araştırma nicel ve nitel tipte yapılmıştır. Bu çalışmanın etik kurul onayı, Hatay Mustafa Kemal Üniversitesi Tıp Fakültesi Girişimsel Olmayan Klinik Araştırmalar etik kurulundan alınmıştır (Tarih: 23/05/2019, karar no: 11). Araştırmanın yapıldı ğı kurumdan yazılı izin alınmıştır. Veriler toplanmadan önce öğrencilere araştırmanın amacı açıklanarak sözel onamları alınmıştır.

Çalışmanın evrenini, bir devlet üniversitesinin ön lisans bölümünde öğrenim gören toplam 542 öğrenci oluşturmuştur. Araştırmada örneklem seçimine gidilmemiş olup, Mayıs-Ekim 2019 tarihleri arasında evrenin tamamına ulaşılması hedeflenmiştir. Çalışmaya katılmayı kabul eden 439 öğrenci ile araştırma tamamlanmıştır. Araştırmanın nitel kısmı için, nicel boyuta katılan ve çalışmanın nitel kısmına katılmaya gönüllü olan öğrencilerden 13’ü rastsal olarak seçilmiş ve görüşmeler yapılmıştır.

Nicel Kısımda Veri Toplama Araçları: Verilerin toplanmasında araştırmacılar tarafından oluşturulan anket formu ${ }^{1,2,6,11}$ ve Nomofobi Ölçeği ${ }^{12}$ kullanılmıştır. Anket formunda öğrencilerin; yaş, cinsiyet, okuduğu sınıf ve cep telefonu kullanma durumları ile ilgili özellikleri belirlemeye yönelik kapalı uçlu sorular yer almıştır. Araştırmanın, nitel kısmı için karma yöntem kullanılmış olup ilk olarak nicel k1sım verileri toplanmıştır daha sonra öğrencilerden görüşmeye katılmak isteyenlerden sözlü onam alınarak nitel kısım için veriler toplanmıştır.

Nomofobi Ölçeği (NMP-Q): 2015 yllında Ylldırım ve Correira ${ }^{12}$ tarafindan geliştirilen ve 2016 yılında Yıldırım vd. ${ }^{13}$ tarafından Türkçe'ye uyarlanan ölçeğe göre 0-20 puan aralığında nomofobi olmadığını, 21-60 puan aralığında düşük düzeyde nomofobi olduğunu, 61-100 puan aralığında orta düzeyde nomofobi olduğunu, 101-140 puan aralığında yüksek düzeyde nomofobi olduğunu göstermektedir. Ölçekte toplam dört alt boyut vardır. Nomofobi ölçeği için Cronbah alpha değeri 0,92 ve alt boyutlar için ise sırasıyla $0,90,0,74,0,94$ ve $.0,91$ olarak belirlenmiştir. $^{12,13} \mathrm{Bu}$ çalışma için Cronbah alpha değeri .91 ve alt boyutlar için ise surasıyla $0,82,0,76,0,90$ ve 0,90 olarak saptanmıştır.

\section{Araştırma Soruları:}

-Ön lisans öğrencilerinin nomofobi düzeyleri nasıldir?

-Ön lisans öğrencilerinin nomofobi düzeyleri çeşitli faktörlere (cinsiyet, sınıf, bölüm ve akıllı telefon kullanım süresi) göre farklılaşmakta mıdır?

Ayrıca, nitel veriler için aşağıdaki sorulara cevap aranmıştır:

-Cep telefonunuzu gün içerisinde sürekli kontrol edermisiniz, uzun süre telefonunuza bakmamanız sizi rahatsiz eder mi?

-Uzun süre cep telefonu kullanımının sağlığınız üzerinde olumsuz etkisinin olduğunu düşünüyor musunuz?

-Cep telefonunuzun hayatınıza girmesiyle birlikte özellikle aile bağlarınızda kopukluk oldu mu? $\mathrm{Bu}$ durum psikolojinizi olumsuz etkiledi mi?

Nitel Kısımda Verilerin Toplanması: Araştırmanın nitel kısmında, nitel araştırmalarda çok yaygın olarak kullanılan durum çalışması yaklaşımı kullanımış olup öğrencilerle odak grup görüşmesi yapılmıştir. 
Araştırmanın nicel ve nitel kısmı, Mayıs-Ekim 2019 tarihleri arasında yapılmış olan anket formu öğrencilere araştırmanın amacı açıklanarak öğrencilerin ders dışı zamanlarında araştırmacı gözetiminde ortalama 10-15 dakika sürecinde uygulanmıştır. Nitel kısım için açık uçlu sorulardan oluşan görüşme formu ortalama 20-25 dakika sürede 7 kadın ve 6 erkek öğrenci olmak üzere toplamda 13 kişi ile tamamlanmıştır.

Verilerin Değerlendirilmesi: Araştırmada elde edilen bulguların analizi SPSS 22.0 (Statistical Package of Social Sciences for Windows) istatistik paket programı değerlendirilmiş olup tanımlayıcı istatistiksel metotların (frekans, yüzde, ortalama, standart sapma) yanı sıra normal dağılımın incelenmesi için Skewness ve Kurtosis $( \pm 1)$ kullanılmıştır. Iç tutarl1lık için Cronbach's alfa ile hesaplanmıştır. İstatistiksel hesaplamaları için bağımsız gruplarda $t$ testi ve tek yönlü varyans analizi (ANOVA) kullanılmıştır. $\mathrm{P}<0,05$ istatiksel anlamlı sonuçlar olarak değerlendirilmiştir. Nitel veriler betimsel istatistikler ile analiz edilmiştir. Araştırmanın nitel kısmı, rastgele seçilen iki görüşme metni üç öğretim üyesi ve araştırmacılar tarafından okunarak bu metinlere ilişkin kodlamalar karşılaştırılmış ve tutarsız olan kodlar analizden çıkarılmıştır.

\section{BULGULAR}

Araştırma bulguları, nicel ve nitel olmak üzere iki ayrı başlık altında incelenmiştir.

Nicel Verilerden Elde Edilen Bulgular: Öğrencilerin yaş ortalaması $20,57 \pm 2,25$ 'dir. \%66,5'i kadın, \% 44,0'1 yurtta kalmakta, \%9,8'inin düzenli olarak kullandığı bir ilacı var, \%8,4'ünün düzenli olarak takip ve tedavi gerektiren bir hastalığının olduğu belirlenmiştir. Telefon kullanma nedenleri olarak \% 86,8 'inin sosyal medyaya göz atmak, $\% 76,3$ 'ünün aile üyeleriyle iletişim kurmak, \%84,3'ünün arkadaşlarla iletişim kurmak, \%65,8'inin internette araştırma yapmak/ eğitsel nedenler, $\% 44,0$ 'ının oyun oynamak, \%78,1'inin müzik dinlemek/ video izlemek, \%44,9'unun alışveriş yapmak, \%33,3'ünün navigasyona bakmak için kullandığı; telefon kullanma durumları \%86,8'inin sıkıldığında, \%66,1'inin yalnız olduğunda, $\% 69,5$ 'inin birini ya da bir şeyi beklerken, $\% 58,5$ 'inin toplu ulaşımda, $\% 56,3$ 'ünün uyandıktan hemen sonra, \%62,6'sinın yatmadan hemen once telefonu ile ilgilendiği belirlenmiştir. Öğrencilerin yaş ile Nomofobi ölçeği "çevirimiçi bağlantıyı kaybetme" alt boyut puan ortalamaları arasında istatistiksel olarak önemli bir ilişki bulunmuştur $(p<0,05)$. Cinsiyet ile toplam Nomofobi ölçe- $\breve{g i}$, "rahatlıktan feragat etme ve iletişimi kuramama" alt boyut puan ortalamaları arasında istatistiksel olarak önemli bir ilişki bulunmuştur $(\mathrm{p}<0,05)$.

Araştırmaya katılan öğrencilerin yanında şarj taşıma, cep telefonunu günlük kontrol etme sıklığı, günlük cep telefonu kullanma süresi, bazen hiçbir bildirim gelmemesine ve daha yeni bakmış olmasına rağmen telefonunu eline alıp sosyal medya hesaplarına tekrar bakıp bakmadığı, gece uyandığında saati kontrol etmek için bile olsa ilk yaptığı şeyin telefona bakıp bakmadığı, son zamanlarda telefonun aile bağlarında kopukluğa sebep olup olmadığ bet etmek için buluştuğunda telefonu sıklıkla kontrol etme ihtiyacı duyup duymadığı durumları arasında Nomofobi ölçeği puan ortalamaları arasında istatistiksel olarak önemli bir ilişki bulunmuştur $(p<0,05)$ (Tablo 1).

Öğrencilerin \%56,5'inin orta düzeyde nomofobi olduğu saptanmıştır. Öğrencilerin Nomofobi düzeyleri ile Nomofobi Ölçeği alt boyut puan ortalamaları arasında istatistiksel olarak önemli bir ilişki saptanmıştır $(\mathrm{p}<0,05)$ (Tablo 2).

Sağ̆lğa İlişkin Nitel Verilerden Elde Edilen Bulgular: Nitel kısım toplamda 13 kişi ile elde edilen bulgular verilmiştir.

Telefona bakamadığında rahatsızlık hisseden katılımcı oranı \%84,6'dır (11 kişi). Örnek ifadeler: "Evet rahatsız oluyorum çünkü hep bir merak içinde oluyorum" "Evet, yoksa aklım telefonumda kalır" "Öyle bir alı̧skanlık ve bağımlık ki sanki bakmadığımda birşeyler eksik ya da güne başlamam mümkün değil gibi”. Telefonuma bakmadığımda o günün huzursuz geçeceğine inanıyorum" (Soru 1).

Cep telefonunun sağlık üzerine olumsuz etkisi olduğunu düşünen katılımcı oranı \%92,3'dür (12 kişi). Örnek ifadeler: "Evet sağlığımı olumsuz etkiliyor çünkü özellikle uzun süreli kullanımda bileklerimde ağrı hissediyorum, duruş pozisyonum değişiyor, konuşma yaptığım taraftaki kulağımda kızarıklık hatta uyuşma hissi oluyor", " Evet, gözlerimde kuruluk oluşuyor, özellikle telefonu tuttuğum elimde belli süreden sonra uyuşma başlıyor, konuşurken kulaklık kullanmazsam başım ciddi derecede ağrımaya başlıyor", "Ailemle okuldan dolayı ayrı yaşadığım için sürekli telefon görüşmesi yapıyorum kulaklık kullanmazsam başım çok ağriyor", "özellikle oyun oynarken ya da telefondan video, film gibi uzun süreli birşeyler izlediğimde gözlerimin yaşardığını hissediyourm”, “ Evet, telefonu kullandığım kolumun ağrıdığını ve uyuştuğunu hissediyourum." "Evet, mesajlaşırken parmaklarımın ve el bileğimin ağrıdığını hissediyorum." 
“Özellikle uzun süreli konuştuğumda fark etmeden başımın öne doğru eğildiğini ve telefonu tuttuğum taraftaki omzumun ağrıdığını hissediyorum" (Soru 2).

Cep telefonunun kullanımının aile bağları ve bireyin psikolojisi üzerinde olumsuz etkisi olduğunu düşünen katılımcı oranı \% 61,5'dir (8 kişi). Örnek ifadeler: "evet aile içinde iletişim neredeyse bitti herkes bir tarafta telefonla ilgileniyor bu durumda psikolojimi olumsuz etkiliyor". Evet, ne yazkkki ailede herkesin telefonu var hiç kimse muhabbet etmek istemiyor ve genelde herkes telefonuyla ilgilenmek istiyor, bu durumda aile içinde kopukluğa neden oluyor, aile içinde ara ara iletişim eksikliğinden dolayı çatışma yaşıyoruz", "Ailemle okuldan dolayı ayrı yaşadığım için sürekli telefon görüşmesi yapıyorum yani aksine telefon aile bağları üzerinde ve psikolojim üzerinde olumsuz etki yapmiyor" (Soru 3).

\section{TARTIŞMA VE SONUÇ}

Günümüzde, teknoloji alanındaki değişimlere paralel olarak toplumda küresel dönüşümler sonucunda internet tabanlı cep telefonlarının gerekliliği giderek artmakta olup nomofobiye sahip kişilerin sayısı gün geçtikçe daha da artmaktadır. ${ }^{6-10 ; 14,15} \mathrm{Bu}$ çalışma ön lisans bölümünde öğrenim gören öğrencilerin nomofobi düzeylerinin bazı faktörler açısından incelenmesi amacıyla yapılmıştır.

Öğrencilerin yaş düzeyleri ile, ölçek alt boyutu olan "Çevirimiçi Bağlantıyı Kaybetme" alt ölçek puan ortalamaları arasında anlamlı bir ilişki saptanmıştır. Literatürde yapılan çalışmalara göre yaş ile nomofobi arasında zit yönlü bir ilişki olduğu ve yaş arttıkça nomofobinin azaldı $\breve{~} 1,{ }^{16,17}$ yapılan başka çalışmalardan elde edilen bulgulara göre ise yaş ile nomofobi arasında bir ilişki olmadığı belirlenmiştir. ${ }^{9,18,19} \mathrm{Bu}$ çalışma ve diğer literatür çalışmaları sınırlı yaş aralığı olan üniversite öğrencileri arasında yapılmış olması, nomofobinin yaş faktöründe farklılaşmasını anlamayı zorlaştırmaktadır. $\mathrm{Bu}$ nedenle, daha geniş yaş grupları arasındaki nomofobi düzeylerinin anlaşılması için karşılaştııılmalı daha fazla çalışmanın yapılması gerektiği düşünülmektedir.

Öğrencilerin cinsiyet ile Nomofobi toplam ölçek, "puan ortalamaları arasında anlamlı bir ilişsi saptanmış olup, kız öğrencilerin Nomofobi toplam ölçek ve alt boyut puan ortalamalarının daha yüksek olduğu belirlenmiştir. Literatürde cinsiyet ile nomofobi arasında bir ilişki olduğu ve kızların nomofobi düzeyinin daha yüksek olduğu saptanmıştır. ${ }^{7,17,20,21}$ Ayrıca cinsiyet ile nomofobi arasında bir ilişki olmadığı sonucu içeren çalışma da mevcuttur. ${ }^{22} \mathrm{Bu}$ çalışmada, kı öğrencilerin "Rahatlıktan Feragat Etme" ve "İletişimi Kuramama" alt boyutlarındaki nomofobi düzeyleri anlamlı şekilde erkeklerden daha yüksek olduğu bulunmuştur. Buna göre kızlar için bu boyutlar erkeklere gore daha önem teşkil etmektedir.

Araştırmaya katılan öğrencilerin yanında şarj taşıma, cep telefonunu günlük kontrol etme sıklığı, günlük cep telefonu kullanma süresi ve arkadaşlarıyla sohbet etmek için buluştuğunda telefonu sıklıkla kontrol etme ihtiyacı duyup duymadığ 1 durumları ile Nomofobi toplam ölçek ve alt boyut puan ortalamaları arasında önemli bir ilişki saptanmıştır. Yanında sarj taşıyan, günlük cep telefonunu $\geq 49 \mathrm{kez}$ kontrol eden, günlük cep telefonunu $>5$ saatin üzerinde kullanan ve arkadaşlarıyla sohbet etmek için buluştuğunda telefonunu sık kontrol eden öğrencilerin Nomofobi toplam ölçek ve alt boyut puan ortalamalarının daha yüksek olduğu tespit edilmiştir (Tablo 1). Nomofobinin belirtileri arasında yanında şarj taşıma, cep telefonunu sık sık kontrol etme ve günlük cep telefonu ile fazla zaman harcama vardır. ${ }^{8}$ Literatürde günlük cep telefonu kullanma süresi $^{17,19,23,24}$ yanında şarj taşıma ${ }^{2,15}$ ve cep telefonunu günlük kontrol etme sıklığ ${ }^{15,16}$ ile nomofobi düzeyleri arasında anlamlı bir ilişki bulunmuştur. Nomofobi sonucu birey telefonuna ulaşamadığında kaygı durumu başlar ve bu durumda bireyin yaşamında günlük işlere yoğunlaşmasını olumsuz etkilemektedir. ${ }^{22} \mathrm{Bu}$ çalışma bulguları, literatür bulguları ile benzerlik göstermektedir. Bu benzerliğin nedeni, cep telefonlarının teknolojik açıdan birden fazla programa sahip olması ve günlük aktiviteler için önemli bir araç olduğu gerçeği olabilir. Ancak, bununda cep telefonlarının kullanım saatlerinin artmasına ve nomofobiye yol açtığı düşünülmektedir.

Araştırmaya katılan öğrencilerin bazen hiçbir bildirim gelmemesine ve daha yeni bakmış olmasına rağmen telefonunu eline alıp sosyal medya hesaplarına tekrar bakıp bakmama ve uyandığında saati kontrol etmek için bile olsa ilk yaptığı şey telefona bakıp bakmadığı durumları ile Nomofobi toplam ölçek ve alt boyut puan ortalamaları arasında önemli bir ilişki saptanmıştır (Tablo 1). Sosyal ağlarda geçirilen süre ve çevirim içi olma, ${ }^{16}$ uyanır uyanmaz telefonunu kontrol etme ${ }^{2,15,16}$ ile nomofobi arasında anlamlı bir ilişki belirlenmiştir. Yapılan bir çalışmada üniversite öğrencileri arasında en yaygın faaliyetin sosyal ağları kontrol etmek olduğu ${ }^{25}$ ve sosyal medya kullanımının cep telefonu bağımlılı̆̆ının 
önemli bir yordayıcısı olduğu bulunmuştur. ${ }^{26}$ Bireylerin yaklaşık \%40'ının akıllı telefonlara sosyal ağları kullanmak amacıyla kullandığı, yaklaşık \% 35'inin telefonun asıl amacı olan iletişim için değil aslında insanların telefona çok bağımlı olduğunu ortaya koymuştur. ${ }^{27} \mathrm{Bu}$ genç yetişkinlerin sosyal davranışlarının yanı sıra zihinsel sağlıklarını da etkileyen cep telefonuna bağımlı hale geldiğini göstermektedir.

Öğrencilerin son zamanlarda telefonun aile bağlarında kopukluğa sebep olup olmadığı durumu ile Nomofobi toplam ölçek ve alt boyut puan ortalamaları arasında önemli bir ilişki saptanmıştır. Son zamanlarda telefonun aile bağlarında kopukluğa sebep olan öğrencilerin Nomofobi toplam ölçek ve alt boyut puan ortalamalarının daha yüksek olduğu tespit edilmiştir (Tablo 2). Aile bağlarındaki kopukluk durumu öğrenciyi daha çok telefon kullanmaya sürüklemiş olabilir.

$\mathrm{Bu}$ çalışmada nomofobi düzeyi, ortanın üzerinde olup $(79,23 \pm 10,03)$, orta ve yüksek nomofobi düzeyine sahip öğrencilerin Nomofobi toplam ölçek puan ortalamalarının daha yüksek olduğu belirlenmiştir (Tablo 2). Literatürde üniversite öğrencileri ile yapılan çalışmalarada, öğrencilerin nomofobi düzeylerinin ortalamanın üzerinde ${ }^{14,28,29}$ ve yüksek düzeyde olduğu bulunmuştur. ${ }^{17} \mathrm{Bu}$ bulgular doğrultusunda, teknolojinin gelişmine paralel olarak telefondaki tüm imkanların kullanımının artması sonucu nomofobininde arttığını söyleyebiliriz. King ve ark. ${ }^{6}$ göre nomofobi günümüzde yükselen önemli bir sorun alanı olarak karşımıza çıktığını ispatlamaktadırlar. Öğrencilerin "İletişimi Kuramama” alt boyutundan en yüksek puanı aldıkları belirlenmiştir ( $\underline{\text { Tablo }}$ 2). Yılmaz ve ark. ${ }^{17}$ yaptıkları çalışmada da aynı sonuca ulaşılmıştır. Dolayısıyla öğrencilerin yakın çevresindeki insanlarla iletişim içinde olma ihtiyacının karşılanamaması durumunda ortaya çıkan korku durumu olan "iletişimi kaybetme" boyutu ile; sağlamak istediği tüm bilgileri telefondan karşılama eğilimini açıklayan "bilgiye ulaşamama" boyutlarının öğrencilerde huzursuzluğa neden olduğu sonucuna ulaşılmıştır. Bu çalışmada öğrencilerin \% 21.0'ının yüksek nomofobi düzeyine sahip olduğu ve saptanmıştır (Tablo 2). Yapılan bir çalışmada, öğrencilerin \%21,0'ının, ${ }^{29} \% 22,0{ }^{\prime}{ }^{\prime} \mathrm{nnn}^{24} \% 23,0$ ' $1 \mathrm{n}^{30}{ }^{30}$ ve $\% 25,3$ 'ünün ${ }^{16}$ yüksek nomofobi düzeyine sahip olduğu belirlenmiştir. Bu çalışmanın bulguları literatür ile benzerlik göstermektedir. Bu çalışma, grubu sağlıkla ilişkili bölümlerde öğrenim gören öğrenciler oluşturmasına rağmen nomofobi düzeyi bu açıdan yüksek bulunmuştur. Oysaki, bu öğrencilerin aşırı internet yada cep telefonu kullanımı sonucunda oluşabilecek sağlık sorunlarını diğer bireylere oranla nispeten daha iyi bilmektedirler. Bu çalışma, bulguları bu açıdan dikkat çekicidir.

Sonuç olarak; Araştırmaya katılan öğrencilerin nomofobi düzeylerinin ortanın üzerinde olduğu, öğrencilerin cep telefonunu günlük olarak sıklıkla kontrol ettiği, bazen hiçbir bildirim gelmemesine ve daha yeni bakmış olmasına rağmen telefonunu eline alıp sosyal medya hesaplarına tekrar baktığı, gece uyandığında saati kontrol etmek için bile olsa ilk yaptığı şeyin telefona bakmak olduğu saptanmıştır. Ayrıca, cep telefonunun sağlık üzerine olumsuz etkisinin olduğunu düşünen öğrencilerin \%92 olduğu; öğrencilerin ifadelerine göre cep telefonunun özellikle göz kuruluğuna, omuz ve baş ağrısına, kullanılan el ve parmakta ağrı, uyuşukluk hissi oluşturduğu belirlenmiştir.

Öğrencilerin nomofobi düzeylerinin azaltılmasına yönelik giderek artan akıllı telefon kullanımı ile ilgili farkındalıklarının arttırılması gerekmektedir. Buna göre öğrencilerin üniversitelerde nomofobiye yönelik farkındalık yaratmak için bilimsel etkinlikler ve psikoeğitim programları düzenlenebilir, kamu spotları hazırlanabilir. Bireylerin nomofobi düzeylerinin özellikle sağlık üzerine olan etkisinin farklı illerde bulunan üniversite ögrrencileriyle ve çocuk, yetişkin gibi farklı örneklem gruplarıyla nicel ve nitel çalışmalar yapılması önerilmektedir. Veri toplama formlarının uygulandığı tarihlerde araştırmaya katılmayı kabul eden öğrencilerden elde edilen verilerle sınırlı olan araştırma, sadece araştırmanın yapıldığı Meslek Yüksek Okulunda okuyan öğrencilere genellenebilir.

Etik Komite Onayı: Çalışmamız Hatay Mustafa Kemal Üniversitesi Girişimsel Olmayan Klinik Araştırmalar Etik Kurulu (Tarih: 23/05/2019, karar no: 11) tarafindan onaylandı

Çıkar Çatışması: Yazarlar çıkar çatışması bildirmemişlerdir.

Yazar Katkıları: Fikir - CBO; Veri toplanması ve işlemesi - $\mathrm{CBO}$, SN, FK ve ED; Analiz ve yorum CBO, FK; Yazıyı yazan - CBO, SN, FK ve ED.

Hakem Değerlendirmesi: Dış bağımsız.

\section{REFERENCES}

1. Anshari M, Alas Y, Hardaker G, et al. Smartphone habit and behavior in Brunei: Personalization, gender, and generation gap. Comput Human Behav. 2016;64:719-727.

2. Sirakaya M. Examination of associate students' 
nomophobia levels according to smart phone use. Mersin Üniversitesi Eğitim Fakültesi Dergisi. 2018;14(2):714-727.

3. Lee S, Kim MW, McDonough IM, et al. The effects of cell phone use and emotion-regulation style on college students' learning. Applied Cognitive Psychology. 2017;31(3):360-6.

4. Oulasvirta A, Rattenbury T, Ma L, et al. Habits make smartphone use more pervasive. Pers Ubiquit Comput. 2012;16(1):105-114.

5. Kang S, Jung J. Mobile communication for human needs: A comparison of smartphone use between the US and Korea. Comput Human Behav. 2014;35:376-387.

6. King ALS, Valença AM, Silva ACO, et al. Nomophobia: Dependency on virtual environments or social phobia? Comput Human Behav. 2013;29 (1):140-144.

7. Augner C, Hacker GW. Associations between problematic mobile phone use and psychological parameters in young adults. Int J Public Health. 2012;57(2):437-441.

8. Bragazzi NL, Del Puente G. A proposal for including nomophobia in the new DSM-V. Psychol Res Behav Manag. 2014;7:155-160.

9. Tavolacci MP, Meyrignac G, Richard L, et al. Problematic use of mobile phone and nomophobia among French college students. Eur J Public Health. 2015;5(3):206.

10. Ozdemir B, Cakir O, Hussain I. Prevalence of Nomophobia among university students: A comparative study of Pakistani and Turkish undergraduate students. EURASIA J Math Sci and Tech Ed. 2018;14(4):1519-1532.

11. Yoğurtçu DD. The relationship between five factor personality traits and nomophobia levels among university students. Yeditepe Universitesi Sosyal Bilimler Enstitüsü Psikoloji ve Rehberlik Bölümü,Yüksek Lsans Tezi. İstanbul, Turkey.2018.

12. Yıldırım C, Correia AP. Exploring the Dimensions of Nomophobia: Development and Validation of a Self-Reported Questionnaire. Computers in Human Behavior,.2015; 49, 130-137.

13. Yıldırım C, Sumuer E, Adnan M, et al. A Growing Fear: Prevalence of Nomophobia Among Turkish College Students. Information Development. 2016;32 (5):1322-1331.

14. Gezgin D, Sumuer E, Arslan O, Yildirim S. Nomophobia Prevalence among Pre-service Teachers: A case of Trakya University. Trakya University Journal of Education Faculty. 2017;7 (1):86-95.
15. Akıllı KG, Gezgin DM. Üniversite öğrencilerinin nomofobi düzeyleri ile farklı davranış örüntülerinin arasındaki ilişkilerin incelenmesi. Mehmet Akif Ersoy Üniversitesi Eğitim Fakültesi Dergisi. 2016;1(40):51-69.

16. Jilisha G, Venkatachalam J, Menon V, et al. Nomophobia: A mixed-methods study on prevalence, associated factors, and perception among college students in puducherry, India. Indian $\mathrm{J}$ Psychol Med. 2019;41(6):541-548.

17. Yılmaz M, Köse A, Doğru YB. Akıllı telefondan yoksun kalmak: nomofobi üzerine bir araştırma. Iletişim ve Bilişim Teknolojileri. 2018;35(9):3142.

18. Aguilera-Manrique G, Ma'rquezHerna'ndez VV, Alcaraz-Co'rdoba $\mathrm{T}$, et al. The relationship between nomophobia and the distraction associated with smartphone use among nursing students in their clinical practicum. PLoS ONE. 2018;13(8): e0202953.

19. Apak E, Yaman MÖ. Üniversite öğrencilerinde nomofobi yaygınlığı ve nomofobi ile sosyal fobi arasındaki ilişki: Bingöl üniversitesi örneklemi. Addicta: The Turkish Journal On Addictions. 2019;6(3):609-627.

20.Gutiérrez-Puertas L, Márquez-Hernández VV, São-Romão-Preto L, et al. Comparative study of nomophobia among Spanish and Portuguese nursingstudents. Nurse Education in Practice. 2019;34:79-84.

21. Gezgin DM, Çakır Ö. Analysis of nomofobic behaviors of adolescents regarding various factors. Journal of Human Sciences. 2016;13 (2):2504-2519.

22. Dixit S, Shukla H, Bhagwat A, et al. A Study To Evaluate Mobile Phone Dependence Among Students of A Medical College and Associated Hospital of Central India. Indian J Community Med. 2010;35(2):339-341.

23. Chandak P, Singh D, Faye A. An exploratory study of nomophobia in post graduate residents of a teaching hospital in Central India. Int J Indian Psychol. 2017;4(3):48-56.

24. Alahmari MS, Alfaifi AA, Alyami AH, et al. Prevalence and risk factors of nomophobia among undergraduate students of health sciences colleges at King Khalid University. Saudi Arabia. Int J Med Res Prof. 2018;4(1):429-432.

25. Salehan M, Negahban A. Social networking on smartphones: when mobile phones become addictive. Comput Human Behav. 2013;29(6):2632 $-2639$.

26. Park SY, Cho SH. Formation of social relation- 
ship through SNS and adolescents' life satisfaction. Journal of Digital Convergence. 2015;13 (2):371-379.

27. Polat R. Dijital hastalik olarak nomofobi. Yeni Medya Elektronik Dergi. 2017;1(2):164-172.

28. Okuyan C, Döner Güner P, Uslusoy Güneş S. Hemşirelik ve Tıp Fakültesi Öğrencilerinin Nomofobi Düzeylerinin Belirlenmesi. Gümüşhane Üniversitesi Sağlı Bilimleri Dergisi. 2019; 8(4):372-382.

29. Kar S, Sharma NN, Mistry C, et al. Prevalence of nomophobia among medical students in a private college of Bhubaneswar, Odisha. Journal of Bio Innovation. 2017;6(6):1-8.

30. Bivin JB, Mathew P, Thulasi PC, et al. Nomophobia - Do we really need to worry about? Reviews of Progress. 2013;1(1):1-5. 
Tablo 1. Öğrencilerin akıllı telefon kullanım özellikler ve nomofobi toplam ölçek ve alt boyut puan ortalamaları dağılımı.

\begin{tabular}{|c|c|c|c|c|c|c|}
\hline & & $\begin{array}{l}\text { Bilgiye } \\
\text { Erişememe }\end{array}$ & $\begin{array}{l}\text { Rahatlıktan } \\
\text { Feragat } \\
\text { Etme } \\
\end{array}$ & $\begin{array}{l}\text { İletişimi } \\
\text { Kuramama }\end{array}$ & $\begin{array}{l}\text { Çevrimiçi } \\
\text { Bağlantıyı } \\
\text { Kaybetme } \\
\end{array}$ & $\begin{array}{l}\text { Nomofobi } \\
\text { Ölçeği Top- } \\
\text { lam }\end{array}$ \\
\hline & $\mathbf{N}(\%)$ & $\mathbf{X} \pm \mathbf{S S}$ & $\mathbf{X} \pm \mathbf{S S}$ & $\mathbf{X} \pm \mathbf{S S}$ & $\mathbf{X} \pm \mathbf{S S}$ & $\mathbf{X} \pm \mathbf{S S}$ \\
\hline \multicolumn{7}{|c|}{ Yanında Şarj Taşıma Durumu } \\
\hline Evet & $166(37,8)$ & $18,25 \pm 6,31$ & $22,28 \pm 7,30$ & $29,07 \pm 9,27$ & $18,10 \pm 8,74$ & $87,72 \pm 24,46$ \\
\hline Hayır & $273(62,2)$ & $16,75 \pm 6,55$ & $18,45 \pm 7,42$ & $26,25 \pm 10,01$ & $16,22 \pm 8,99$ & $77,68 \pm 25,73$ \\
\hline Önemlilik* & & $\mathrm{p}=\mathbf{0 , 0 1 9}$ & $\mathrm{p}=\mathbf{0 , 0 0 1}$ & $\mathrm{p}=\mathbf{0 , 0 0 3}$ & $\mathbf{p}=\mathbf{0 , 0 3 3}$ & $\mathrm{p}=\mathbf{0 , 0 0 1}$ \\
\hline \multicolumn{7}{|c|}{ Cep Telefonunu Günlük Kontrol Etme Sıklığı } \\
\hline $1-16 \mathrm{kez}$ & $95(21,6)$ & $14,66 \pm 6,65$ & $16,90 \pm 7,24$ & $24,71 \pm 9,95$ & $14,72 \pm 8,54$ & $71,01 \pm 24,51$ \\
\hline $17-32 \mathrm{kez}$ & $101(23,0)$ & $16,61 \pm 5,93$ & $18,81 \pm 6,98$ & $26,08 \pm 9,51$ & $16,34 \pm 8,59$ & $77,86 \pm 23,46$ \\
\hline $33-48 \mathrm{kez}$ & $79(18,0)$ & $17,74 \pm 5,71$ & $19,64 \pm 6,81$ & $27,29 \pm 8,77$ & $17,16 \pm 8,64$ & $81,84 \pm 22,86$ \\
\hline$\geq 49 \mathrm{kez}$ & $164(37,4)$ & $19,09 \pm 6,55$ & $22,43 \pm 7,78$ & $29,60 \pm 9,99$ & $18,46 \pm 9,27$ & $89,59 \pm 26,48$ \\
\hline Önemlilik** & & $\mathrm{p}=\mathbf{0 , 0 0 1}$ & $\mathrm{p}=0,001$ & $\mathrm{p}=\mathbf{0 , 0 0 1}$ & $\mathrm{p}=\mathbf{0 , 0 1 1}$ & $\mathrm{p}=0,001$ \\
\hline \multicolumn{7}{|c|}{ Günlük Cep Telefonu Kullanma Süresi } \\
\hline$<1$ saat & $13(3,0)$ & $13,46 \pm 8,16$ & $14,53 \pm 8,80$ & $21,84 \pm 11,27$ & $13,53 \pm 8,50$ & $63,38 \pm 28,51$ \\
\hline 1-3 saat & $123(28,0)$ & $15,63 \pm 6,47$ & $17,12 \pm 6,53$ & $24,02 \pm 10,56$ & $14,93 \pm 8,69$ & $71,71 \pm 24,92$ \\
\hline 3-5 saat & $147(33,5)$ & $17,18 \pm 5,80$ & $20,17 \pm 6,97$ & $27,90 \pm 8,75$ & $16,45 \pm 8,44$ & $81,71 \pm 22,43$ \\
\hline$>5$ saat & $156(35,5)$ & $19,10 \pm 6,53$ & $22,28 \pm 7,98$ & $29,83 \pm 9,23$ & $19,24 \pm 9,14$ & $90,46 \pm 25,60$ \\
\hline Önemlilik** & & $\mathrm{p}=\mathbf{0 , 0 0 1}$ & $\mathrm{p}=0,001$ & $\mathrm{p}=\mathbf{0 , 0 0 1}$ & $p=0,001$ & $p=0,001$ \\
\hline \multicolumn{7}{|c|}{$\begin{array}{l}\text { Bazen Hiçbir Bildirim Gelmemesine Ve Daha Yeni Bakmış Olmasına Rağmen Telefonunu Eline Alıp } \\
\text { Sosyal Medya Hesaplarına Tekrar Bakma Durumu }\end{array}$} \\
\hline Evet & $351(80,0)$ & $17,72 \pm 6,33$ & $20,60 \pm 7,50$ & $27,79 \pm 9,84$ & $17,79 \pm 9,07$ & $83,92 \pm 25,65$ \\
\hline Hayır & $88(20,0)$ & $15,69 \pm 6,90$ & $17,10 \pm 7,40$ & $25,43 \pm 9,59$ & $13,48 \pm 7,46$ & $71,71 \pm 23,60$ \\
\hline Önemlilik* & & $\mathrm{p}=\mathbf{0 , 0 0 1}$ & $\mathrm{p}=0,001$ & $\mathrm{p}=0,042$ & $p=0,001$ & $\mathrm{p}=0,001$ \\
\hline \multicolumn{7}{|c|}{ Gece Uyandığında Saati Kontrol Etmek İçin Bile Olsa İlk Yaptığı Şey Telefona Bakmak Mı? } \\
\hline Evet & $344(78,4)$ & $17,88 \pm 6,44$ & $20,89 \pm 7,52$ & $28,47 \pm 9,50$ & $17,67 \pm 9,08$ & $84,92 \pm 25,36$ \\
\hline Hayır & $95(21,6)$ & $15,98 \pm 6,43$ & $16,29 \pm 6,78$ & $23,15 \pm 9,88$ & $14,26 \pm 7,87$ & $69,00 \pm 22,99$ \\
\hline Önemlilik* & & $\mathrm{p}=\mathbf{0 , 0 0 1}$ & $\mathrm{p}=\mathbf{0 , 0 0 1}$ & $\mathrm{p}=\mathbf{0 , 0 0 1}$ & $\mathrm{p}=\mathbf{0 , 0 0 1}$ & $\mathrm{p}=\mathbf{0 , 0 0 1}$ \\
\hline \multicolumn{7}{|c|}{ Son Zamanlarda Telefon, Aile Bağlarında Kopukluğu Sebep Oldu Mu? } \\
\hline Evet & $116(26,4)$ & $18,26 \pm 6,24$ & $22,16 \pm 7,29$ & $28,19 \pm 9,15$ & $18,96 \pm 8,84$ & $87,59 \pm 25,59$ \\
\hline Hayır & $323(73,6)$ & $16,98 \pm 6,56$ & $19,08 \pm 7,56$ & $27,00 \pm 10,05$ & $16,20 \pm 8,87$ & $79,28 \pm 2,541$ \\
\hline Önemlilik* & & $\mathrm{p}=0,067$ & $\mathrm{p}=\mathbf{0 , 0 0 1}$ & $\mathrm{p}=0,264$ & $p=0,004$ & $\mathrm{p}=\mathbf{0 , 0 0 3}$ \\
\hline \multicolumn{7}{|c|}{$\begin{array}{l}\text { Arkadaşlarıyla Sohbet Etmek İçin Buluştuğunda Telefonu Sıklıkla Kontrol Etme İhtiyacı Duyuyor } \\
\text { Mu? }\end{array}$} \\
\hline Evet & $223(50,89$ & $18,13 \pm 6,30$ & $21,61 \pm 7,23$ & $28,33 \pm 9,77$ & $17,87 \pm 8,97$ & $85,95 \pm 25,56$ \\
\hline Hayır & $216(49,2)$ & $16,48 \pm 6,60$ & $18,13 \pm 7,59$ & $26,27 \pm 9,79$ & $15,95 \pm 8,81$ & $16,85 \pm 25,06$ \\
\hline Önemlilik* & & $\mathrm{p}=0,008$ & $\mathrm{p}=\mathbf{0 , 0 0 1}$ & $\mathrm{p}=\mathbf{0 , 0 2 8}$ & $\mathrm{p}=\mathbf{0 , 0 2 4}$ & $\mathrm{p}=\mathbf{0 , 0 0 1}$ \\
\hline \multicolumn{7}{|c|}{ Telefonun Hafızası Her Zaman İçin Dolu Mu? } \\
\hline Evet & $231(52,6)$ & $18,47 \pm 6,27$ & $21,43 \pm 7,54$ & $28,53 \pm 9,67$ & $18,11 \pm 8,94$ & $86,55 \pm 25,07$ \\
\hline Hayır & $208(47,4)$ & $16,03 \pm 6,51$ & $18,20 \pm 7,32$ & $25,97 \pm 9,84$ & $15,62 \pm 8,76$ & $75,84 \pm 25,25$ \\
\hline Önemlilik* & & $\mathrm{p}=\mathbf{0 , 0 0 1}$ & $p=0,001$ & $p=0,006$ & $p=0,003$ & $p=0,001$ \\
\hline
\end{tabular}

* Bağımsız gruplarda t testi, **ANOVA testi, $\mathrm{X} \pm$ SS: Ortalama \pm Standart Sapma. 
Tablo 2. Öğrenciler in nomofobi düzeylerinin ve nomofobi ölçeği alt boyut puan ortalamalarına göre dağılımı.

\begin{tabular}{|l|l|l|l|l|l|l|}
\hline & & $\begin{array}{c}\text { Bilgiye } \\
\text { Erişememe }\end{array}$ & $\begin{array}{c}\text { Ra- } \\
\text { hatlıktan } \\
\text { Feragat } \\
\text { Etme }\end{array}$ & $\begin{array}{c}\text { İletişimi } \\
\text { Kuramama }\end{array}$ & $\begin{array}{c}\text { Çevrimiçi } \\
\text { Bağlantıyı } \\
\text { Kaybetme }\end{array}$ & $\begin{array}{c}\text { Nomofobi } \\
\text { Toplam } \\
\text { Ölçek }\end{array}$ \\
\cline { 2 - 7 } & $\mathbf{N} \mathbf{( \% )}$ & $\mathbf{X} \pm \mathbf{S S}$ & $\mathbf{X} \pm \mathbf{S S}$ & $\mathbf{X} \pm \mathbf{S S}$ & $\mathbf{X} \pm \mathbf{S S}$ & $\mathbf{X} \pm \mathbf{S S}$ \\
\hline $\begin{array}{l}\text { Nomofobi yok (0-20 } \\
\text { puan aralığında) }\end{array}$ & $3(0,7)$ & $4,00 \pm 0,00$ & $5,00 \pm 0,00$ & $6,00 \pm 0,00$ & $5,00 \pm 0,00$ & $20,0 \pm 0,00$ \\
\hline $\begin{array}{l}\text { Düşük düzeyde } \\
\text { nomofobi (21-59 puan } \\
\text { aralığında) }\end{array}$ & $80(18,2)$ & $11,78 \pm 5,83$ & $11,65 \pm 4,48$ & $13,91 \pm 6,60$ & $7,97 \pm 3,40$ & $45,32 \pm 10,43$ \\
\hline $\begin{array}{l}\text { Orta düzeyde nomofobi } \\
(60-99 \text { puan aralığında) }\end{array}$ & $248(56,5)$ & $16,93 \pm 5,66$ & $19,23 \pm 5,50$ & $27,61 \pm 6,60$ & $15,45 \pm 6,60$ & $79,23 \pm 10,03$ \\
\hline $\begin{array}{l}\text { Yüksek düzeyde } \\
\text { nomofobi (100-140 } \\
\text { puan aralığında) }\end{array}$ & $108(24,6)$ & $22,68 \pm 4,03$ & $27,96 \pm 5,30$ & $37,18 \pm 4,11$ & $27,28 \pm 6,35$ & $115,12 \pm 12,39$ \\
\hline Önemlilik & & $* \mathbf{p}=\mathbf{0 , 0 0 1}$ & $* \mathbf{p}=\mathbf{0 , 0 0 1}$ & $* \mathbf{p}=\mathbf{0 , 0 0 1}$ & $* \mathbf{p}=\mathbf{0 , 0 0 1}$ & $* \mathbf{p}=\mathbf{0 , 0 0 1}$ \\
\hline Toplam & $17,32 \pm 6,49$ & $19,90 \pm 7,60$ & $27,32 \pm 9,82$ & $16,93 \pm 8,93$ & $81,48 \pm 25,69$ \\
\hline
\end{tabular}

* Bağımsız gruplarda t testi, X \pm SS: Ortalama \pm Standart Sapma. 